\title{
Efektivitas sabun antibakteri terhadap penurunan biofilm pada luka kaki diabetik: Literature review
}

\author{
Muhrawi Yunding ${ }^{1^{*}}$, Saldy Yusuf ${ }^{2}$, Takdir Tahir ${ }^{3}$, Fitria Amrullah ${ }^{4}$ \\ 1,2,3,4 Fakultas IImu Keperawatan Universitas Hasanudin, Indonesia \\ *Coresponding Author: ymuhrawi@yahoo.com
}

\begin{abstract}
Abstrak
Pendahuluan: Luka Kaki Diabetik (LKD) merupakan penyakit dengan proses penyembuhan yang lama. LKD yang mengalami keterlambatan penyembuhan diakibatkan oleh adanya biofilm pada luka. Prognosis penderita LKD yang mengalami infeksi cukup buruk, seperti amputasi dan kematian. Tindakan dalam mengontrol biofilm pada penderita LKD diperlukan, salah satunya adalah dengan pencucian luka yang efektif menggunakan sabun antibakteri. Tujuan dari tinjauan ini adalah untuk mengetahui efektivitas pencucian luka dengan menggunakan sabun antibakteri terhadap penurunan biofilm. Metode: Tinjauan ini merupakan sebuah scoping review dengan menggunakan data based Pubmed, Proquest, Science Direct and Willey. Hasil: Terdapat 307 artikel yang didapatkan dari 4 database, sebanyak 10 artikel yang memenuhi kriteria inklusi. Mayoritas artikel membahas tentang efek chlorhexidine terhadap biofilm sebanyak 9 artikel dan hanya 1 artikel membahas tentang efek Parachlorometxylenol (PMCX). CHG mampu mereduksi bakteri hingga 8 unit log CFU (> 99,99 \%) dan biofilm, CHG dalam menghilangkan stapilococcus aureus (6 hingga $>8 \log 10)$, PMCX efektif melawan Staphylococcus aureus dan $P$. aeruginosa penyebab infeksi nasokomial. Simpulan: Pencucian luka dengan menggunakan sabun antibakteri mampu menghilangkan biofilm dan telah terbukti lebih efektif dibandingkan dengan pencucian dengan air saja. Efek antibakteri lebih efektif jika dikombinasikan dengan terapi lain seperti ozon.
\end{abstract}

Kata kunci: Chlorhexidine, CHG, PMCX, dettol, biofilm

\section{The effectiveness of antibacterial soap on biofilm decreased in diabetic foot ulcer: Literature review}

\begin{abstract}
Introduction: Diabetic Foot Ulcer (DFU) is a disease with a long healing process, DFU that experience delays in healing are caused by the presence of biofilms in wounds. amputation. Thus an action is needed in controlling the biofilm in patients with DFU, one of which is wound cleaning which is effective using antibacterial soap. The purpose of this review is to determine the effectiveness of wound washing using antibacterial soap against biofilm reduction. Methods: This review is a scoping review using data based Pubmed, Proquest, Science Direct and Willey. Results: There were 307 articles obtained from 4 databases, 10 articles that met the inclusion criteria, 1 article from the USA, 5 articles from Brazil and 4 from the UK. The majority of articles discuss 9 effects of chlorhexidine on biofilms and only 1 article discusses the effects of Parachlorometxylenol (PMCX). CHG is able to reduce bacteria to 8 units of CFU log (> 99.99\%) and biofilms, CHG in removing stapilococcus aureus (6 to> 8 log10), PMCX is effective against Staphylococcus aureus and P. aeruginosa causes of nasocomial infection. Conclusions: Washing wounds using antibacterial soap is able to eliminate biofilms and has proven to be more effective than water washing alone. Antibacterial effects are more effective when combined with other therapies such as ozone.
\end{abstract}

Keywords: Chlorhexidine, CHG, PMCX, dettol, biofilm

How to Cite: Yunding, M., Yusuf, S., Tahir, T., \& Amrullah, F. (2020). Efektivitas sabun antibakteri terhadap penurunan biofilm pada luka kaki diabetic: Literature review. NURSCOPE: Jurnal Penelitian dan Pemikiran IImiah Keperawatan, 6(1), 34-46 


\section{PENDAHULUAN}

Luka kaki diabetik (LKD) merupakan salah satu komplikasi pada penderita diabetes mellitus, penelitian kami sebelumnya mengkonfirmasikan prevalensi resiko LKD di Indonesia masih sangat tinggi, yaitu $55.4 \%$ (Yusuf et al., 2016), dengan prevalensi LKD sebesar $12.0 \%$ (Yusuf et al., 2016). LKD membutuhkan sekitar 12 bulan untuk proses penyembuhan (Ndosi et al., 2017). LKD merupakan penyakit dengan proses penyembuhan yang lama.

LKD yang mengalami keterlambatan penyembuhan sangat rentan terhadap bakteri. Sekitar 70,8 \% LKD mengandung biofilm (Mahrous, Abdelmoety, Yehia, \& Ghonaim, 2016). Biofilm dapat mengakibatkan infeksi, sekitar 48,9\% penderita LKD mengalami infeksi (Chen, Giurini, \& Karchmer, 2017). Prognosis penderita LKD yang mengalami infeksi cukup buruk, seperti amputasi dan kematian (Ndosi et al., 2017). Sebuah hasil penelitian menyebutkan peranan LKD terhadap kejadian amputasi mencapai 5,8 $\%$ dari 644 subjek yang diteliti (Mendes. et al., 2015). Dengan demikian diperlukan sebuah tindakan dalam mengontrol kejadian infeksi pada penderita LKD yang tepat salah satunya adalah dengan pencucian luka.

Saat ini ada banyak pilihan pencucian luka yang dapat digunakan, diantaranya : air kran (tap water), normal saline (Chan, Cheung, \& Leung, 2016), povidone iodine, chlorhexidine gluconate (Kulkarni \& Awode, 2013) dan sabun (Abbas, Hussain, Hussain, Ali, \& Abbas, 2016). Penggunaan sabun juga berkontribusi dalam hal kontrol biofilm. sebuah penelitian menunjukan bahwa chlorhexidine (CHG) efektif dalam menghilangkan biofilm (Ariani et al., 2015) dan sabun yang mengandung Chloroxylenol diketahui juga memiliki efek dalam menghilangkan biofilm (Zoccolotti et al., 2018). CHG juga diketahui mampu menghambat pertumbuhan planktonik pembentuk biofilm (Vestby \& Nesse, 2015), Sabun antibakteri telah banyak digunakan dalam pencegahan infeksi, namun masih efek sabun antibakteri terhadap biofilm pada luka kaki masih belum diketahui sehingga dibutuhkan sebuah tinjaun tentang sabun antibakteri terhadap biofilm.

\section{METODE}

Tujuan review ini untuk mengidentifikasi efektifitas pencucian luka menggunakan sabun antibakteri terhadap penurunan biofilm. Pertanyaan penelitian dalam review ini 'Apakah sabun antibakteri dapat mengurangi biofilm ?'. Framework penelitian antara lain, Konsep, Pencucian luka dengan menggunakan sabun antibakteri untuk pembersihan dinilai efektif, aman dan murah. Pencucian berguna untuk menyiapkan dasar luka, mengurangi bakteri dan mencegah aktivitas biofilm. Beberapa kandungan sabun antibakteri adalah chlorhexidine (CHG) Parachlorometxylenol atau chloroxylenol (PMCX). Konteks, Biofilm merupakan sebuah arsitektur koloni mikroorganisme yang dilingkupi oleh matriks substansi polimerik ekstraseluler yang mereka hasilkan. Secara epidemiologi biofilm telah terbukti dapat menyebabkan infeksi, oleh karna itu dibutuhkan beberapa strategi intervensi untuk menghilangkan biofilm. Adapun Kriteria inklusi dan eksklusi dalam review ini, berfokus pada artikel tentang penggunaan sabun antibakteri untuk penurunkan biofilm, artikel kuantitatif, penggunaan sabun antibakteri dan biofilm, sedangkan artikel review kami eksklusi. Strategi pencarian, Data based yang kami gunakan dalam review ini adalah Pubmed, Proquest, Science Direct and Willey dengan menggunakan kata kunci untuk data base Pubmed, Proquest, Science Direct : ((diabetic foot ulcers) OR DFU) AND (biofilm) AND ((soap antibacterial) OR (soap antimicrobial) OR soap OR chlorhexidine OR Parachlorometxylenol OR Chloroxylenol). sedangkan untuk Willey digunakan kata kunci "diabetic foot ulcers AND biofilm AND soap antimicrobial". Pencarian kami batasi pada artikel dengan full text, berbahasa inggris, antara tahun 2013 sampai 2018. Google scholar digunakan sebagai tambahan pencaraian data sekunder. 


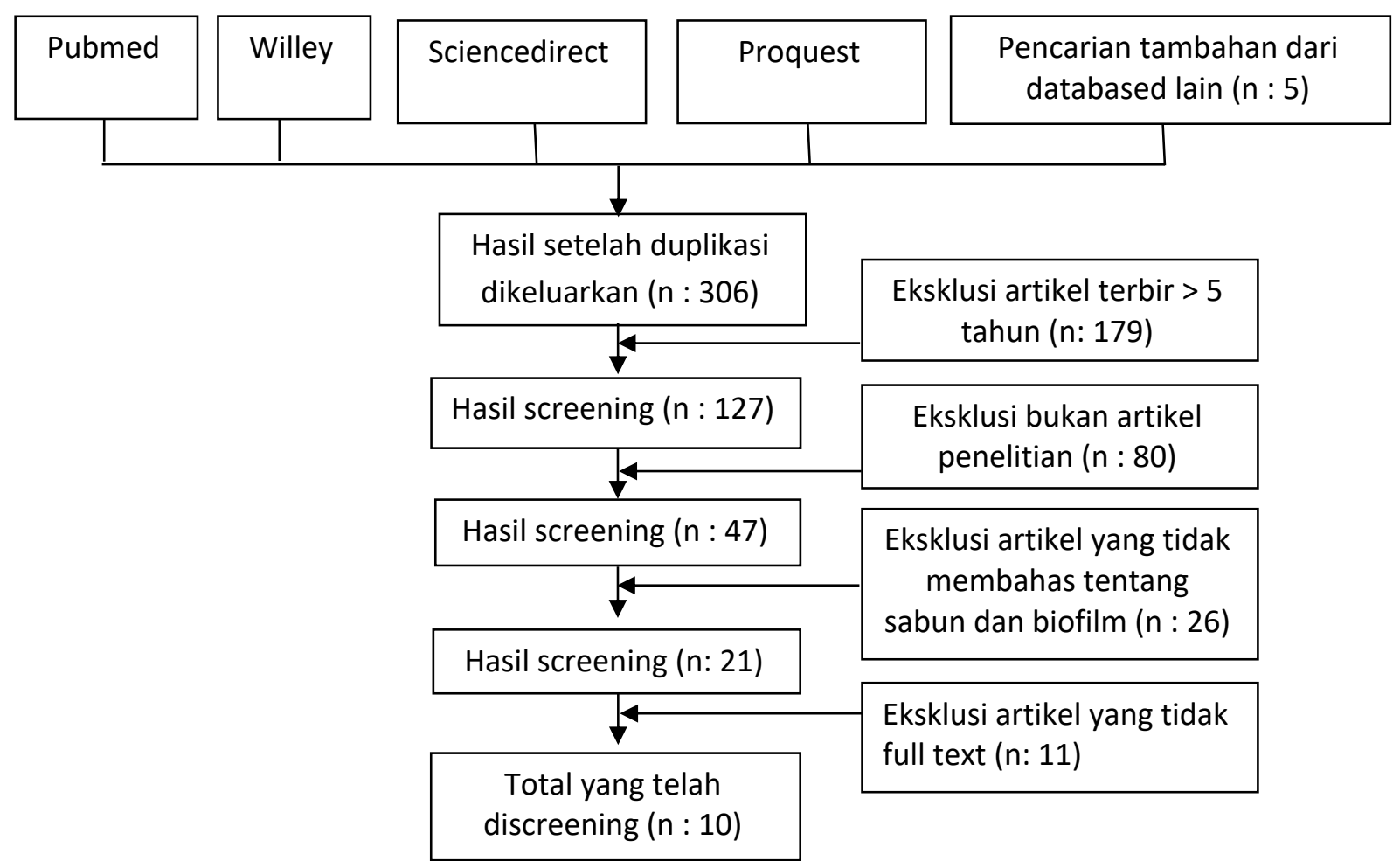

Gambar 1. Algoritma pencarian

Tabel 1. Sintesis grid

\begin{tabular}{|c|c|c|c|c|c|c|}
\hline Author/tahun & Negara & Tujuan & Populasi & Metode & Intervensi & Hasil \\
\hline $\begin{array}{l}\text { (Zoccolotti et } \\
\text { al., 2018) }\end{array}$ & $\begin{array}{l}\text { Virginia, } \\
\text { USA }\end{array}$ & $\begin{array}{l}\text { mengevaluasi } \\
\text { sifat fisik dan } \\
\text { biologis dari } \\
\text { resin akrilik } \\
\text { dasar gigi } \\
\text { tiruan setelah } \\
\text { perendaman } \\
\text { dalam sabun } \\
\text { antiseptik. }\end{array}$ & $\begin{array}{l}\text { pasien yang } \\
\text { mengalami } \\
\text { stomatitis } \\
\text { pada gigi } \\
\text { tiruan }\end{array}$ & $\begin{array}{l}\text { Experimental } \\
\text { grup }\end{array}$ & $\begin{array}{l}\text { Di lakukan } \\
\text { perendaman } \\
\text { pada gigi tiruan } \\
\text { dengan } \\
\text { menggunakan } \\
\text { sabun } \\
\text { antibakteri pada } \\
\text { waktu } \\
\text { perendaman } \\
\text { yang berbeda } \\
\text { pada setiap } \\
\text { kelompok. }\end{array}$ & $\begin{array}{l}\text { Terdapat perbedaan } \\
\text { yang signifikan pada } \\
\text { setiap kelompok } \\
\text { dibandingkan satu } \\
\text { sama lain }(p=0,014) \text {. } \\
\text { Dettol (PMCX) dan } \\
\text { Lifebuoy dapat } \\
\text { menghilangkan } \\
\text { biofilm yang sudah } \\
\text { terbentuk pada } \\
\text { spesimen. }\end{array}$ \\
\hline $\begin{array}{l}\text { (Ariani et al., } \\
2015 \text { ) }\end{array}$ & $\begin{array}{l}\text { UK, } \\
\text { inggris }\end{array}$ & $\begin{array}{l}\text { Menilai } \\
\text { efektivitas } \\
\text { agen } \\
\text { pembersih } \\
\text { yang berbeda } \\
\text { dalam } \\
\text { membunuh } \\
\text { spesies } \\
\text { campuran } \\
\text { biofilm pada } \\
\text { prostesis } \\
\text { wajah silikon }\end{array}$ & $\begin{array}{l}\text { Pasien } \\
\text { dengan } \\
\text { prostesis } \\
\text { wajah } \\
\text { silikon }\end{array}$ & $\begin{array}{l}\text { an in vitro } \\
\text { study }\end{array}$ & 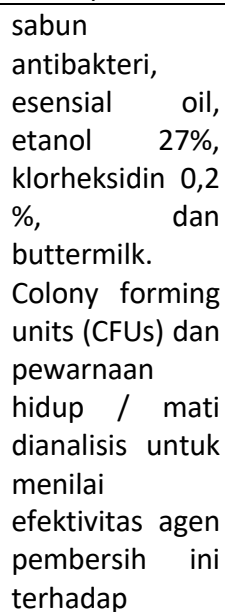 & $\begin{array}{lr}\text { CHG adalah agen } \\
\text { pembersihan yang } \\
\text { paling efektif. CHG } \\
\text { membunuh } 8 \text { unit log } \\
\text { CFU (> } 99,99 \% \\
\text { pembunuhan) } 24 \text { jam } \\
\text { biofilm dan } 5 \text { unit log } \\
\text { CFU (> 99,99\% } \\
\text { pembunuhan) dalam } \\
\text { 2- minggu. }\end{array}$ \\
\hline
\end{tabular}




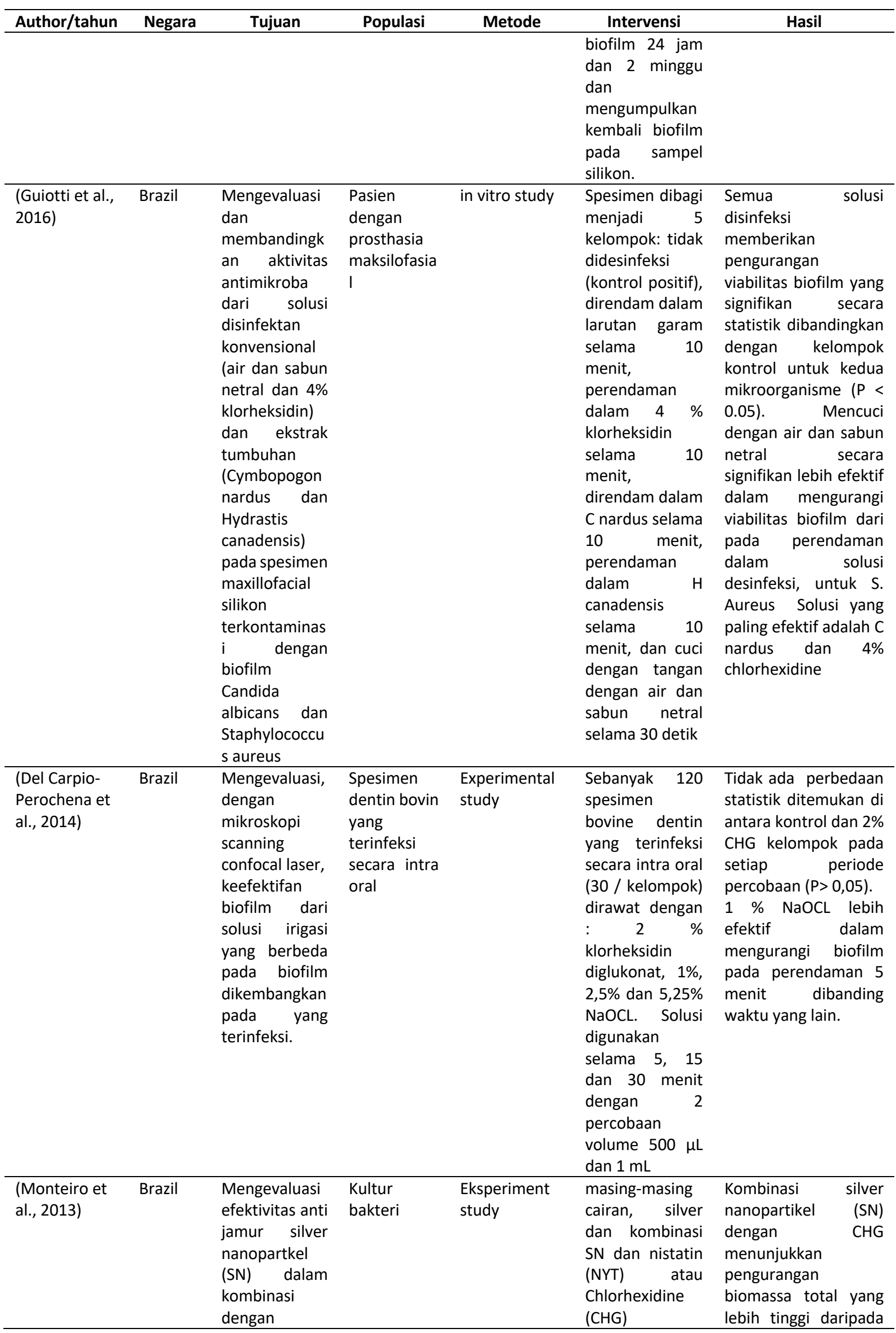




\begin{tabular}{|c|c|c|c|c|c|c|}
\hline Author/tahun & Negara & Tujuan & Populasi & Metode & Intervensi & Hasil \\
\hline & & $\begin{array}{l}\text { nistatin (NYT) } \\
\text { atau } \\
\text { klorheksidin } \\
\text { diglukonat } \\
\text { (CHG) } \\
\text { terhadap } \\
\text { Candida } \\
\text { albicans dan } \\
\text { biofilm } \\
\text { Candida } \\
\text { glabrata }\end{array}$ & & & $\begin{array}{l}\text { ditambahkan ke } \\
\text { preformed } \\
\text { biofilm dan } \\
\text { lempeng } \\
\text { mikrotiter dan } \\
\text { diinkubasi pada } \\
37^{\circ} \text { C selama } 24 \\
\text { jam (di bawah } \\
120 \text { rpm). }\end{array}$ & $\begin{array}{l}\text { kombinasi SN dengan } \\
\text { NYT. kombinasi SN } \\
\text { dengan CHG mampu } \\
\text { mengurangi secara } \\
\text { signifikan }(\mathrm{P}<0,05) \text {, }\end{array}$ \\
\hline $\begin{array}{l}\text { (Touzel et al., } \\
\text { 2016b) }\end{array}$ & Inggris & $\begin{array}{l}\text { Membentuk } \\
\text { model biofilm } \\
\text { multi - spesies } \\
\text { untuk menguji } \\
\text { kemanjuran } \\
\text { formula yang } \\
\text { mengandung } \\
\text { klorheksidin } \\
\text { dan klorheksidin } \\
\text { dalam pemberantasa } \\
\text { n biofilm } \\
\text { polimikroba }\end{array}$ & $\begin{array}{l}\text { Kultur } \\
\text { bakteri }\end{array}$ & In vitro study & $\begin{array}{l}\text { Dressing luka } \\
\text { yang terdiri dari } \\
\text { kasa direndam } \\
\text { dalam } 0,5 \% \\
\text { CHG atau } \\
\text { tersedia secara } \\
\text { komersial } \\
\text { Dressing Tulle } \\
\text { Gras diresapi } \\
\text { dengan } \\
\text { klorheksidin } \\
\text { 0,5\%. Dressing } \\
\text { kontrol adalah } \\
\text { kasa steril. Plate } \\
\text { diinkubasi } \\
\text { selama 24 jam } \\
\text { pada } 370 \quad \text { C } \\
\text { sebelum } \\
\text { bioreaktor } \\
\text { diswab dan } \\
\text { dicuci dua kali } \\
\text { dalam PBS steril } \\
\text { sebelum cfu / } \\
\text { kupon untuk } \\
\text { setiap spesies } \\
\text { bakteri } \\
\text { ditentukan. } \\
\text { Semua } \\
\text { eksperimen } \\
\text { dilakukan dalam } \\
\text { rangkap tiga. }\end{array}$ & $\begin{array}{l}\text { Ketika media kultur } \\
\text { bakteri ditanamkan di } \\
\text { dasar luka simulasi, } \\
\text { dibentuk di piring } \\
\text { agar, dressing medis } \\
\text { yang mengandung } \\
\text { Chlorhexidine (CHG) } \\
\text { sepenuhnya } \\
\text { menghilangkan } \\
\text { aureus (> } 8 \text { log10 } \\
\text { pengurangan), tetapi } \\
\text { memiliki efek minimal } \\
\text { (<3 log10) terhadap } \\
\text { spesies lain yang diuji. }\end{array}$ \\
\hline $\begin{array}{l}\text { (Townsend, } \\
\text { Sherry, } \\
\text { Rajendran, } \\
\text { Hansom, } \\
\text { Butcher, } \\
\text { Mackay, } \\
\text { Williams, \& } \\
\text { Ramage, } \\
\text { 2016) }\end{array}$ & Inggris & $\begin{array}{l}\text { Menciptakan } \\
\text { novel biofilm } \\
\text { luka bakar in- } \\
\text { vitro } \\
\text { model pada } \\
\text { substrat } \\
\text { selulosa } \\
\text { berbasis } \\
\text { hidrogel yang } \\
\text { kompleks } \\
\text { untuk menguji } \\
\text { perawatan } \\
\text { luka topikal } \\
\text { yang biasa } \\
\text { digunakan }\end{array}$ & $\begin{array}{l}\text { Kultur } \\
\text { bakteri }\end{array}$ & In vitro study & $\begin{array}{l}\text { Kedua bakteri } \\
\text { ditumbuhkan } \\
\text { dan } \\
\text { dipertahankan } \\
\text { pada } 37^{\circ} \mathrm{C} \text { pada } \\
\text { agar Luria } \\
\text { kemudian } \\
\text { kedua kultur di } \\
\text { beri cairan } \\
\text { antimikrobial } \\
\text { iodine povidone } \\
\text { dan chlorhexidine. } \\
\text { chlor }\end{array}$ & 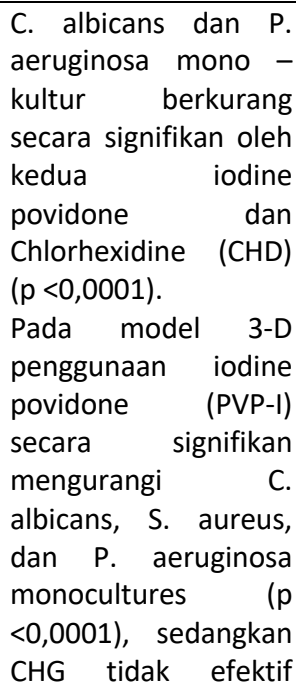 \\
\hline
\end{tabular}




\begin{tabular}{|c|c|c|c|c|c|c|}
\hline Author/tahun & Negara & Tujuan & Populasi & Metode & Intervensi & $\begin{array}{c}\text { Hasil } \\
\end{array}$ \\
\hline & & & & & & $\begin{array}{l}\text { untuk keduanya } C \text {. } \\
\text { albicans dan } P \text {. } \\
\text { aeruginosa }(p<0,05) \text {. }\end{array}$ \\
\hline $\begin{array}{l}\text { (Johani et al., } \\
\text { 2017b) }\end{array}$ & Inggris & $\begin{array}{l}\text { Uji kinerja } \\
\text { solusi luka } \\
\text { antimikroba } \\
\text { topikal } \\
\text { terhadap } \\
\text { penggunaan } \\
\text { biofilm } \\
\text { mikroba } \\
\text { in vitro, ex vivo } \\
\text { dan in vivo } \\
\text { model sistem } \\
\text { pada waktu } \\
\text { pemaparan } \\
\text { yang relevan } \\
\text { secara klinis }\end{array}$ & $\begin{array}{l}\text { pada } 10 \\
\text { pasien } \\
\text { dengan } \\
\text { ulkus kaki } \\
\text { kronis tanpa } \\
\text { penyembuh } \\
\text { an diabetes } \\
\text { rumit oleh } \\
\text { biofilm }\end{array}$ & $\begin{array}{l}\text { in vitro to in } \\
\text { vivo }\end{array}$ & $\begin{array}{l}\text { Pencuci luka } \\
\text { antimikroba } \\
\text { topikal diuji di } \\
\text { bawah tiga } \\
\text { kondisi yang } \\
\text { berbeda: (in } \\
\text { vitro) 4\% b / v } \\
\text { Minyak } \\
\text { melaleuca, } \\
\text { polyhexamethyl } \\
\text { ene biguanide, } \\
\text { chlorhexidine, } \\
\text { povidone iodine } \\
\text { dan asam } \\
\text { hipoklorus } \\
\text { terhadap } \\
\text { biofilm matang } \\
\text { Staphylococcus } \\
\text { aureus dan } \\
\text { Pseudomonas } \\
\text { aeruginosa; (ex } \\
\text { vivo) asam } \\
\text { hipoklorus diuji } \\
\text { terhadap } 3 \text { hari } \\
\text { biofilm P. } \\
\text { aeruginosa } \\
\text { dewasa; dan (in } \\
\text { vivo) 4\% w / v } \\
\text { minyak } \\
\text { Melaleuca. }\end{array}$ & 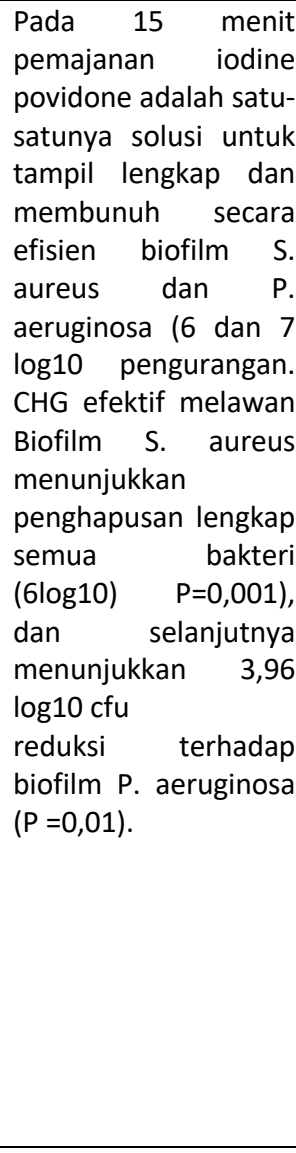 \\
\hline $\begin{array}{l}\text { (Queiroz et } \\
\text { al., 2016) }\end{array}$ & Brazil & $\begin{array}{l}\text { Mengevaluasi } \\
\text { pengaruh } \\
\text { medium kultur } \\
\text { terhadap efek } \\
\text { respons dosis } \\
\text { chlorhexidine } \\
\text { (CHX) pada } \\
\text { biofilm } \\
\text { Streptococcus } \\
\text { mutans UA159 } \\
\text { dan memvalidasi } \\
\text { penggunaan } \\
\text { kaldu yang } \\
\text { disesuaikan } \\
\text { dengan kation } \\
\text { Muller Hinton } \\
\text { (MH) untuk } \\
\text { evaluasi } \\
\text { aktivitas } \\
\text { antibakteri }\end{array}$ & $\begin{array}{l}\text { Kultur } \\
\text { bakteri }\end{array}$ & $\begin{array}{l}\text { Experimental } \\
\text { study }\end{array}$ & 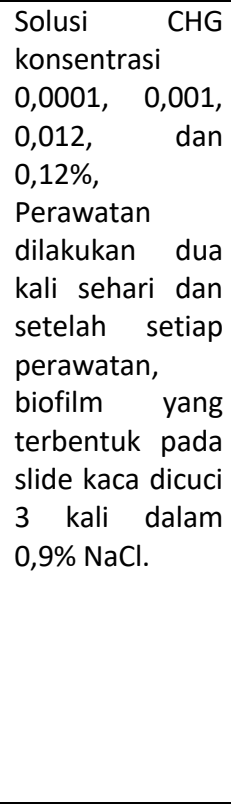 & $\begin{array}{l}\text { Efek kecenderungan } \\
\text { signifikan secara } \\
\text { statistik ( } p \leq 0,002 \text { ) } \\
\text { ditemukan di antara } \\
\text { konsentrasi CHG, } \\
\text { media kultur memang } \\
\text { mempengaruhi efek } \\
\text { respons dosis CHG } \\
\text { pada biofilm } \\
\text { Streptococcus mutans } \\
\text { dan bahwa MH } \\
\text { (Muller-Hinton) dapat } \\
\text { digunakan untuk } \\
\text { aktivitas antibakteri }\end{array}$ \\
\hline $\begin{array}{l}\text { (Borges, } \\
\text { Elias, da } \\
\text { Silva, et } \\
\text { al., 2017) }\end{array}$ & Brazil & $\begin{array}{l}\text { Mengevaluas } \\
\mathrm{i} \\
\text { sitotoksisitas } \\
\text { ozon di } \\
\text { fibroblas }\end{array}$ & Kultur sel & $\begin{array}{l}\text { Experiment } \\
\text { al study }\end{array}$ & $\begin{array}{l}\text { Sel dikultur } \\
\text { dalam } \\
\text { medium } \\
\text { Elang } \\
\text { Dulbecco }\end{array}$ & \\
\hline
\end{tabular}




\begin{tabular}{|c|c|c|c|c|c|c|}
\hline Author/tahun & Negara & $\begin{array}{l}\text { Tujuan } \\
\end{array}$ & Populasi & Metode & Intervensi & Hasil \\
\hline & 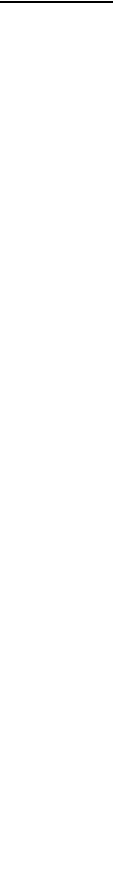 & $\begin{array}{l}\text { (L929) dan } \\
\text { keratinocytes } \\
\text { (HaCat) garis } \\
\text { sel, efeknya } \\
\text { pada migrasi } \\
\text { sel dan } \\
\text { aktivitas } \\
\text { antimikroban } \\
\text { ya. }\end{array}$ & & & $\begin{array}{l}\text { yang } \\
\text { dimodifikasi } \\
\text { selanjutnya, } \\
\text { Sel-sel } \\
\text { diobati } \\
\text { dengan salin } \\
\text { buffer fosfat } \\
\text { terionisasi (8, } \\
4,2,1,0,5 \\
\text { dan } 0,25 \mu g \text { / } \\
\text { mL ozon), } \\
\text { chlorhexidin } \\
\text { e } 0,2 \% \text { atau } \\
\text { larutan } \\
\text { buffered, dan } \\
\text { viabilitas sel } \\
\text { adalah } \\
\text { ditentukan } \\
\text { melalui MTT } \\
\text { assay }\end{array}$ & \\
\hline
\end{tabular}

\section{HASIL DAN PEMBAHASAN}

Berdasarkan hasil pencarian artikel yang dikumpulkan adalah 307 artikel, setelah dilakukan screning dengan mengeluarkan artikel yang double, terbit $>5$ tahun, bukan artikel penelitian, tidak membahas sabun dan biofilm dan tidak full text maka menghasilkan 10 artikel yang memenuhi kriteria inklusi, 1 artikel dari USA, 5 artikel dari brazil dan 4 dari inggris. (Tabel 1), mayoritas artikel membahas tentang efek chlorhexidine terhadap biofilm sebanyak 9 artikel dan hanya 1 artikel membahas tentang efek Parachlorometxylenol (PMCX), metode dari masing-masing artikel adalah : eksperimental study terdapat 4 artikel, in vitro study 5 artikel, dan 1 artikel dengan pendekatan RCT.

Efek chlorhexidine terhadap biofilm.

CHG merupakan senyawa kimia yang menjadi salah satu kandungan dari sabun antibakteri, dalam review ini terdapat 2 artikel di lakukan pada pasien gigi tiruan (Carpio-perochena, Bramante, Antonio, Duarte, \& Andrade, 2014; Zoccolotti et al., 2018), 2 artikel yang meneliti biofilm pada silicone maxilofacial (Ariani et al., 2015; Guiotti et al., 2016), 4 artikel dilakukan dengan kultur bakteri (Borges, Elias, Silva, et al., 2017; Queiroz et al., 2016; Touzel, Sutton, \& Wand, 2016; Townsend, Sherry, Rajendran, Hansom, Butcher, Mackay, Williams, Ramage, et al., 2016) dan 1 artikel di lakukan pada pasien luka kaki diabetic (Johani et al., 2017a). metode terbanyak yang digunakan adalah in vitro pada 5 artikel, 3 artikel menggunakan metode eksperimental study 2 pada klinis dan 1 dilakukan di lab, 1 artikel dengan RCT.

Penggunaan sabun antibakteri dapat di kombinasikan dengan antibakteri lain. Pada salah satu artikel, penggunaan CHG di kombinasikan dengan sabun antibakteri, esensial oil, etanol $27 \%$, dan buttermilk di gunakan untuk melihat efektifitas dari agen pembersih terhadap biofilm (Ariani et al., 2015), intervensi lainnya pada silikon maxillofacial yang terkontaminasi biofilm di rendam dalam 5 cairan antimikroba berbeda antara lain, larutan garam, CHG $4 \%$, cymbopogon nardus, hydrastis canadensis dan sabun netral (Guiotti et al., 2016). Selanjutnya pemberian CHG $2 \%$, dan sodium hypochlorite ( $\mathrm{NaOCl})$ 1\%, 2,5\% dan 5,25\%, pada masing kelompok, cairan digunakan selama 5, 15 dan 30 menit dengan 2 percobaan volume $500 \mu \mathrm{L}$ dan $1 \mathrm{~mL}$ (Carpio-perochena et al., 2014). Penelitian berikutnya menggunakan intervensi penggunaan silver dan kombinasi silver (SN) dan nistatin (NYT) atau CHG 
(Monteiro et al., 2013). Selain dikombinasikan, terdapat juga artikel yang membandingkan antara CHG dengan solusi lain.

Terdapat juga artikel yang membandingkan antara penggunaan CHG dengan bahan lain. Sebuah artikel membandingkan antara dressing luka yang terdiri dari kasa direndam dalam 0,5\% CHG dengan Dressing Tulle Gras yang tersedia secara komersil. Dressing kontrol adalah kasa steril pada piring diinkubasi selama 24 jam pada $37^{\circ} \mathrm{C}$, Semua eksperimen dilakukan dalam rangkap tiga untuk melihat efektifitas dari cairan antimikrobial terhadap biofilm (Touzel, Sutton, \& Wand, 2016). Penelitian yang membandingkan iodine povidone dan CHG melakukan intervensi pada kedua bakteri yang ditumbuhkan dan dipertahankan pada $37^{\circ} \mathrm{C}$ pada agar Luria kemudian kedua kultur di beri cairan antimikrobial iodine povidone dan CHG untuk melihat efek dari ke dua cairan antimikroba tersebut (Townsend, Sherry, Rajendran, Hansom, Butcher, Mackay, Williams, \& Ramage, 2016). Ke dua penelitian ini membandingkan efek antimikroba pada dua jenis bahan antimikroba.

Artikel lain membandingkan CHG dengan beberapa bahan antimikroba, sebuah penelitian in vitro membandingkann $4 \%$ b / v Minyak melaleuca, polyhexamethylene biguanide, CHG, povidone iodine dan asam hipoklorus terhadap biofilm matang Staphylococcus aureus dan Pseudomonas aeruginosa, secara ex vivo asam hipoklorus diuji terhadap 3 hari biofilm P. aeruginosa dewasa; dan in vivo 4\% w / $\checkmark$ minyak Melaleuca diaplikasikan pada 10 pasien dengan ulkus kaki kronis tanpa penyembuhan diabetes diakibatkan oleh biofilm (Johani et al., 2017b). Selanjutnya sebuah penelitian yang menggunakan $\mathrm{NaCl}$ 0,9\%, CHX $1 \mu \mathrm{g} / \mathrm{mL}, \mathrm{CHX} 10 \mu \mathrm{g} / \mathrm{mL}, \mathrm{CHX} 120 \mu \mathrm{g} / \mathrm{mL}$ diberikan selama 1 menit, dua kali sehari, selama 3 hari yang di tambahkan ke masing-masing kultur biofilm untuk mengetahui jenis antimikroba yang paling efektif dalam mereduksi biofilm (Queiroz et al., 2016). Artikel yang terakhir menjelaskan tentang penggunaan CHG pada sel dikultur dalam medium Elang Dulbecco yang dimodifikasi selanjutnya sel-sel diobati dengan salin buffer fosfat terionisasi $(8,4,2,1,0,5$ dan 0,25

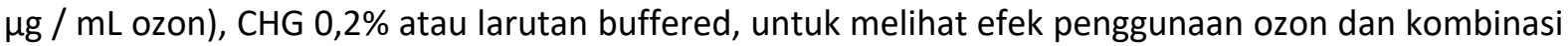
antara ozon dan CHG atau laurutan buffered (Borges, Elias, da Silva, et al., 2017).

\section{Efek Parachlorometxylenol (PMCX) / Dettol / chloroxylenol terhadap biofilm}

PMCX / Dettol merupakan salah satu zat yang terkandung dalam sabun antibakterial. Satu penelitian yang di lakukan pada pasien yang mengalami stomatitis pada penggunaan gigi tiruan dengan menggunakan metode eksperimental study, adapun intevensi yang dilakukan adalah dengan melakukan perendaman gigi tiruan menggunakan sabun antibakteri pada 4 kelompok yang berbeda untuk melihat efek dari sabun antibakteri terhadap biofilm (Zoccolotti et al., 2018).

Biofilm merupakan selaput bening yang dihasilkan oleh bakteri sebagai pertahanan diri. Standar penanganan biofilm adalah dengan mekanikal debridement (Wolcott et al., 2010), tapi dapat mengakibatkan nyeri dan ketidaknyamanan (Haryanto, 2018), sehingga dibutuhkan alternatif lain dalam mengotrol infeksi dan biofilm pada luka salah satunya adalah pencucian luka dengan sabun antibakteri. Penggunaan sabun sebagai agen pembersih telah di kenal sejak zaman dahulu. Sabun antibakteria mengandung beberapa zat diantaranya adalah chlorhexidine (CHG) (Johani et al., 2017) dan Parachlorometxylenol atau chloroxylenol (PMCX) (Zoccolotti et al., 2018), ke dua zat tersebut di ketahui mampu menurunkan jumlah bakteri dan biofilm.

Efek chlorhexidine terhadap penurunan biofilm.

Beberapa hasil temuan dari review ini adalah penggunaan CHG pada pasien yang menggunakan gigi tiruan dan protesa wajah. Satu penelitian menunjukkan hasil tidak adanya perbedaan yang signifikant penggunaan $\mathrm{CHG} 2 \%$ dengan penggunaan $\mathrm{NaOCL}$ dalam menghilangkan biofilm, keduanya mampu mereduksi biofilm, pada penggunaan CHG $4 \%$ terdapat hubungan yang signifikant dengan pengurangan biofilm pada gigi tiruan (Carpio-perochena et al., 2014). Penelitian lain penggunaan CHG 
sebagai cairan pembersih dan antimikroba yang efektif dalam mereduksi biofilm pada pengguna prostesa wajah, efek CHG dalam membunuh bakteri hingga 8 unit log CFU (> 99,99 \%) (Ariani et al., 2015). Penelitian yang menggunakan prostesa wajah yang lain menemukan CHG $4 \%$ efektif untuk biofilm S. Aureus (Guiotti et al., 2016). Penelitian tersebut menyatakan bahwa CHG dan cairan antimikrobial lain mampu mereduksi biofilm pada permukaan polimer gigi tiruan dan protesa wajah.

Penggunaan CHG dengan koombinasi alat juga efektif dalam mengurangi biofilm. Satu penelitian tentang penggunaan $\mathrm{CHG}$ yang dikombinasikan dengan alat ozon menyimpulkan bahwa CHG dengan kombinasi antimikroba maupun alat mampu mereduksi biofilm lebih efektif (Borges, Elias, Silva, et al., 2017). Penelitian lain menyatakan kombinasi electronic apex locator (EAL) dengan CHG mampu mereduksi koloni bakteri (Froughreyhani, Salemmilani, Mozafari, \& Hosein-soroush, 2018). Komnbinsi CHG dengan alat disimpulkan efektif menghilangkan biofilm.

Penggunaan CHG sebagai cairan antimikroba juga efektif dalam mereduksi biofilm. Penelitian tentang efek CHG dalam menghilangkan stapilococcus aureus (6 hingga > 8 log10) (Johani et al., 2017; Touzel et al., 2016; Townsend, Sherry, Rajendran, Hansom, Butcher, Mackay, Williams, \& Ramage, 2016). CHG mampu mereduksi biofilm utamanya pada bakteri stapilococcus aureus yang merupakan salah satu jenis bakteri gram positif (Nurwahidah, Yusuf, \& Tahir, 2018). CHG merupakan antibakteri dan disinfektan yang mempunyai efek bakterisidal dan bakteriostatik terhadap bakteri Gram (+) dan Gram (-) (Poureslam, Barkam, Poureslami, Salari, \& Salari, 2014; Yousefimanesh \& Amin, 2015). CHG lebih efektif terhadap bakteri Gram (+) dibandingkan dengan bakteri Gram (-).

CHG efektif membunuh bakteri dengan cara mengikat dinding sel bakteri. Dinding sel bakteri bermuatan negatif sedangkan chlorhexidine bermuatan positif sehngga CHG dapat mengikat dengan kuat dinding sel bakteri yang bermuatan negatif (Edmiston, Okoli, Graham, Sinski, \& Seabrook, 2010). CHG akan berikatan dengan fosfolipid membran cell bagian dalam merusak membran sel prokariota dan mengganggu konstituen sitoplasmiknya (Erdem, Sepet, Kulekci, Trosola, \& Guven, 2012), menyebabkan sitoplasma rusak dan kebocoran komponen dinding sel yang mengakibatkan kematian sel (Cheung et al., 2012). CHG efektif dalam membunuh bakteri penghasil biofilm.

Efek Parachlorometxylenol (PMCX) / Dettol / chloroxylenol terhadap biofilm.

Zat kimia lain yang terkandung dalam sabun antibakteri adalah PMCX. sebuah penelitian tentang penggunaan sabun antibakteri PMCX terhadap biofilm menunjukkan bahwa sabun dengan PMCX efektif dalam mengurangi biofilm pada spesiment gigi tiruan (Zoccolotti et al., 2018). PMCX dapat menghambat pertumbuhan bakteri gram positif dan bakteri gram negative (Gargi, R, Hs, \& Rahul, 2017). PMCX efektif melawan Staphylococcus aureus (Aldabbagh, Ali, Khalil, \& Hamad, 2015). Peneltian lain menunjukkan hasil bahwa $P M C X$ adalah agen yang mematikan terhadap $P$. aeruginosa penyebab infeksi nasokomial (Verma \& Verma, 2018). Fakta-fakta ini mengaskan potensi PMCX yang terkandung dalam sabun antibakteri dapat mengurangi biofilm.

\section{SIMPULAN DAN SARAN}

Secara umum sabun antibakteri mampu menghilangkan bakteri dan biofilm, dan efektifitasnya semakin baik ketika di kombinasikan dengan bahan lain seperti antimikrobial lain atau terapi lain yang menggunakan alat seperti ozon dan electronic apex locator (EAL), selain efektif dalam mereduksi biofilm, sabun juga mudah didapat dan murah. selanjutnya dibutuhkan penelitian lebih lanjut untuk mengetahui efek dari sabun antibakteria terhadap penurunan bakteri dan biofilm.

\section{DAFTAR PUSTAKA}

Abbas, S., Hussain, K., Hussain, Z., Ali, R., \& Abbas, T. (2016). Anti-Bacterial Activity of Different Soaps Available in Local Market of Rawalpindi (Pakistan) against Daily Encountered Bacteria. 
Pharmaceutica Analytica Acta, 7(11), 10-13. https://doi.org/10.4172/2153-2435.1000522

Aldabbagh, S., Ali, H. H., Khalil, I. I., \& Hamad, M. A. (2015). A Study Of Some Antibiotics; Disinfectants and Antiseptics Efficacy Against Some Species Of Pathogenic Bacteria. Assiut Veterinary Medical Journal, 61(147), 210-217. Retrieved from http://www.aun.edu.eg/journal_files/437_J_8466.pdf

Ariani, N., Visser, A., Teulings, M. R. I. M., Dijk, M., Rahardjo, T. B. W., Vissink, A., \& van der Mei, H. C. (2015). Efficacy of cleansing agents in killing microorganisms in mixed species biofilms present on silicone facial prostheses-an in vitro study. Clinical Oral Investigations, 19(9), 2285-2293. https://doi.org/10.1007/s00784-015-1453-0

Borges, G. Á., Elias, S. T., da Silva, S. M. M., Magalhães, P. O., Macedo, S. B., Ribeiro, A. P. D., \& Guerra, E. N. S. (2017). In vitro evaluation of wound healing and antimicrobial potential of ozone therapy. Journal of Cranio-Maxillofacial Surgery, 45(3), 364-370. https://doi.org/10.1016/j.jcms.2017.01.005

Borges, G. Á., Elias, S. T., Silva, S. M. M. da, Magalhães, P. de O., Macedo, S. B., Ribeiro, A. P. D., \& Guerra, E. N. S. (2017). In vitro evaluation of wound healing and antimicrobial potential of ozone therapy. Journal of Cranio-Maxillofacial Surgery, 45(3), 364-370. https://doi.org/10.1016/j.jcms.2017.01.005.This

Carpio-perochena, A., Bramante, C. M., Antonio, M., Duarte, H., \& Andrade, F. B. De. (2014). Application of laser scanning microscopy for the analysis of oral bio fi Im dissolution by different endodontic irrigants. Dental Research Journal, 11(4), 442-447. https://doi.org/10.4103/17353327.139417

Chan, M. C., Cheung, K., \& Leung, P. (2016). Tap Water Versus Sterile Normal Saline in Wound Swabbing. Journal Wound Ostomy Continence Nurs, 43(2), 140-147. https://doi.org/10.1097/WON.0000000000000213

Chen, S.-Y., Giurini, J. M., \& Karchmer, A. W. (2017). Invasive Systemic Infection Following Hospital Treatment for Diabetic Foot Ulcer: Risk of Occurrence and Effect on Survival. Clinical Infectious Diseases Advance Access, 64(3), 326-334. https://doi.org/https://doi.org/10.1093/cid/ciw736

Cheung, H., Wong, M. M., Cheung, S., Liang, L. Y., Lam, Y., \& Chiu, S. (2012). Differential Actions of Chlorhexidine on the Cell Wall of Bacillus subtilis and Escherichia coli. PLOS ONE, 7(5). https://doi.org/10.1371/journal.pone.0036659

Del Carpio-Perochena, A., Bramante, C. M., Hungaro Duarte, M. A., de Andrade, F. B., Cavenago, B. C., Villas-Bôas, M. H., ... Amoroso-Silva, P. (2014). Application of laser scanning microscopy for the analysis of oral biofilm dissolution by different endodontic irrigants. Dental Research Journal, 11(4), 442-447. Retrieved from http://www.pubmedcentral.nih.gov/articlerender.fcgi?artid=4163821\&tool=pmcentrez\&rende rtype=abstract

Edmiston, C. E., Okoli, O., Graham, M. B., Sinski, S., \& Seabrook, G. R. (2010). Evidence for Using Chlorhexidine Gluconate Preoperative Cleansing to Reduce the Risk of Surgical Site Infection. AORN Journal, 92(5), 509-518. https://doi.org/10.1016/j.aorn.2010.01.020 
Erdem, A. P., Sepet, E., Kulekci, G., Trosola, S. C., \& Guven, Y. (2012). Effects of Two Fluoride Varnishes and One Fluoride / Chlorhexidine Varnish on Streptococcus mutans and Streptococcus sobrinus Biofilm Formation in Vitro. Intteerrnattiionall Jourrnall off Meediiccall Scciieencceess, 2(9), 129136. https://doi.org/10.7150/ijms.3637

Froughreyhani, M., Salemmilani, A., Mozafari, A., \& Hosein-soroush, M. (2018). Effect of electric currents on antibacterial effect of chlorhexidine against Entrococcus faecalis biofilm : An in vitro study. Journal of Clinical and Experimental Dentistry, 10(12), 1223-1229. https://doi.org/10.4317/jced.55369

Gargi, R., R, P. M., Hs, V., \& Rahul, J. (2017). Efficacy study of some antiseptics and disinfectants. International J. of Life Sciences, 5(4), 593-598.

Guiotti, A. M., Cunha, B. G., Paulini, M. B., Goiato, M. C., dos Santos, D. M., Duque, C., ... Gottardo de Almeida, M. T. (2016). Antimicrobial activity of conventional and plant-extract disinfectant solutions on microbial biofilms on a maxillofacial polymer surface. Journal of Prosthetic Dentistry, 116(1), 136-143. https://doi.org/10.1016/j.prosdent.2015.12.014

Haryanto. (2018). Identidikasi Biofilm dan Efektifitas Topikal Komplementari Menggunakan New Method Terhadap Penyembuhan Luka Kaki Diabetes Di Indonesia. Jurnal Luka Indonesia, 4(2).

Johani, K., Malone, M., Jensen, S. O., Dickson, H. G., Gosbell, I. B., Hu, H., ... Vickery, K. (2017a). Evaluation of short exposure times of antimicrobial wound solutions against microbial biofilms : from in vitro to in vivo. Journal of Antimicrobial Chemotherapy, 73(2), 494-502. https://doi.org/10.1093/jac/dkx391

Johani, K., Malone, M., Jensen, S. O., Dickson, H. G., Gosbell, I. B., Hu, H., ... Vickery, K. (2017b). Evaluation of short exposure times of antimicrobial wound solutions against microbial biofilms: from in vitro to in vivo. Journal of Antimicrobial Chemotherapy, (January), 1-9. https://doi.org/10.1093/jac/dkx391

Kulkarni, A. P., \& Awode, R. M. (2013). A prospective randomised trial to compare the efficacy of povidone-iodine $10 \%$ and chlorhexidine $2 \%$ for skin disinfection. Indian Journal of Anaesthesia, 57(3), 270-275. https://doi.org/10.4103/0019-5049.115619

Mahrous, S., Abdelmoety, H., Yehia, M., \& Ghonaim, R. (2016). The Prevalence of Biofilm in Diabetic Foot Patients in Zagazig University Hospital , Egypt. International Journal of Science and Research, 5(8), 2038-2045. https://doi.org/10.21275/ART20161041

Mendes., D. M., Monteiro-Soares, M., Boyko, E. J., Ribeiro, M., Barata, P., Lima, J., \& Soares, R. (2015). The independent contribution of diabetic foot ulcer on lower extremity amputation and mortality risk. J Diabetes Complications, 28(5), 632-638. https://doi.org/10.1016/j.jdiacomp.2014.04.011.The

Monteiro, D. R., Silva, S., Negri, M., Gorup, L. F., de Camargo, E. R., Oliveira, R., ... Henriques, M. (2013). Antifungal activity of silver nanoparticles in combination with nystatin and chlorhexidine digluconate against Candida albicans and Candida glabrata biofilms. Mycoses, 56(6), 672-680. https://doi.org/10.1111/myc.12093

Ndosi, M., Wright-hughes, A., Brown, S., Lipsky, B. A., Bhogal, M., Reynolds, C., ... Nelson, E. A. (2017). 
Prognosis of the infected diabetic foot ulcer: a 12-month prospective observational study. Research Article, 0-2. https://doi.org/10.1111/dme.13537

Nurwahidah, Yusuf, S., \& Tahir, T. (2018). Identifikasi jenis bakteri pada luka kaki diabetik berdasarkan penyebab luka di rumah perawatan luka dan poliklinik luka di kota makassar. Jurnal Kesehatan Manarang, 4(2), 97-103.

Poureslam, H., Barkam, F., Poureslami, P., Salari, Z., \& Salari, S. (2014). Comparison of Antibacterial Effect of Fluoride and Chlorhexidine on Two Cariogenic Bacteria : An in Vitro Study. Journal of Dental Biomaterials, 1(1), 27-31.

Queiroz, V. S. De, Ccahuana-vásquez, R. A., Tedesco, A. F., Lyra, L., Cury, J. A., \& Schreiber, A. Z. (2016). Influence of the Culture Medium in Dose-Response Effect of the Chlorhexidine on Streptococcus mutans Biofilms. Scientifica, 1-7. https://doi.org/10.1155/2016/2816812

Touzel, R. E., Sutton, J. M., \& Wand, M. E. (2016a). Establishment of a multi-species biofilm model to evaluate chlorhexidine efficacy. Journal of Hospital Infection, 92, 154-160.

Touzel, R. E., Sutton, J. M., \& Wand, M. E. (2016b). Establishment of a multi-species biofilm model to evaluate chlorhexidine efficacy. Journal of Hospital Infection, 92(2), 154-160. https://doi.org/10.1016/j.jhin.2015.09.013

Townsend, E. M., Sherry, L., Rajendran, R., Hansom, D., Butcher, J., Mackay, W. G., ... Hansom, D. (2016). Development and characterisation of a novel three-dimensional inter-kingdom wound biofilm model. The Journal of Bioadhesion and Biofilm Research, 7014(November). https://doi.org/10.1080/08927014.2016.1252337

Townsend, E. M., Sherry, L., Rajendran, R., Hansom, D., Butcher, J., Mackay, W. G., ... Ramage, G. (2016). Development and characterisation of a novel three-dimensional inter-kingdom wound biofilm model. Biofouling, 32(10), 1259-1270. https://doi.org/10.1080/08927014.2016.1252337

Verma, P., \& Verma, M. K. (2018). Antimicrobial activity of Antibiotics and Antiseptics ( Dettol and Betadine ) against Clinical Isolates of Pseudomonas aeruginosa. International Journal of Life Sciences Scientific Research, 1589-1598. https://doi.org/10.21276/ijlssr.2018.4.1.14

Vestby, L. K., \& Nesse, L. L. (2015). Wound care antiseptics - performance differences against Staphylococcus aureus in biofilm. Acta Veterinaria Scandinavica, 57(22), 1-5. https://doi.org/10.1186/s13028-015-0111-5

Wolcott, R. d., Rumbaugh, K. ., James, G., Schultz, G., Phillips, P., Yang, Q., ... Dowd, S. e. (2010). Biofilm maturity studies indicate sharp debridement opens a time- dependent therapeutic window. Journal of Wound Care, 19(8), 320-328. https://doi.org/https://doi.org/10.12968/jowc.2010.19.8.77709

Yousefimanesh, H., \& Amin, M. (2015). Comparison of the Antibacterial Properties of Three Mouthwashes Containing Chlorhexidine Against Oral Microbial Plaques: An in vitro Study. Jundishapur Journal of Microbiology, 8(2), 4-7. https://doi.org/10.5812/jjm.17341

Yusuf, S., Okuwa, M., Irwan, M., Rassa, S., Laitung, B., Thalib, A., ... Sugama, J. (2016). Prevalence and Risk Factor of Diabetic Foot Ulcers in a Regional Hospital, Eastern Indonesia. Open Journal of 
Nursing, 06(01), 1-10. https://doi.org/10.4236/ojn.2016.61001

Zoccolotti, J. D. O., Tasso, C. O., Isabel, M., Arbela, A., Malavolta, I. F., Carolina, E., ... Jorge, J. H. (2018a). Properties of an acrylic resin after immersion in antiseptic soaps: Low-cost, easy-access procedure for the prevention of denture stomatitis. PLOS ONE, 13(8), 1-22. https://doi.org/https://doi. org/10.1371/journal.pone.0203187

Zoccolotti, J. D. O., Tasso, C. O., Isabel, M., Arbela, A., Malavolta, I. F., Carolina, E., ... Jorge, J. H. (2018b). Properties of an acrylic resin after immersion in antiseptic soaps : Low-cost, easy-access procedure for the prevention of denture stomatitis, 58, 1-22. 